\title{
ACTIVITY OF NATURAL RADIONUCLIDES AND THEIR CONTRIBUTION TO THE ABSORBED DOSE IN THE FISH CUBERA SNAPPER (Lutjanus cyanopterus, Cuvier, 1828) ON THE COAST OF CEARA, BRAZIL*
}

\author{
Wagner de S. Pereira ${ }^{1,2, * *}$, Alphonse Kelecom ${ }^{2,3}$ and Delcy de A. Py Júnior ${ }^{1}$ \\ ${ }^{1}$ Coordenação de Proteção Radiológica de Caldas \\ Unidade de Tratamento de Minérios, Indústrias Nucleares do Brasil S.A. \\ (Caixa Postal 961, 37701-970 Poços de Caldas, MG, Brasil) \\ **wspereira@inb.gov.br \\ ${ }^{2}$ Universidade Federal Fluminense - Instituto de Biologia \\ Programa de Pós-Graduação em Biologia Marinha, Laboratório de Radiobiologia e Radiometria \\ (Caixa Postal 100.644, 24001-970 Niterói, RJ, Brasil) \\ ${ }^{3}$ Universidade Federal Fluminense - Instituto de Geociências \\ Programa de Pós-Graduação em Ciência Ambiental \\ (Caixa Postal 107.092, 24360-970 Niterói, RJ, Brasil)
}

\begin{abstract}
A B S T R A C T
A methodology was developed for converting the activity concentration of radionuclides $\left(\mathrm{Bq} \mathrm{kg}^{-1}\right)$ into absorbed dose rate $\left(\mathrm{Gy} \mathrm{y}^{-1}\right)$, aiming an approach to environmental radioprotection based on the concept of standard dose limit. The model considers only the internal absorbed dose rate. This methodology was applied to the cubera snapper fish (Lutjanus cyanopterus, Cuvier, 1828) caught off the coast of Ceará. The natural radionuclides considered were uranium-238, radium-226, lead-210, thorium-232 and radium-228. The absorbed dose rates were calculated for individual radionuclides and the type of emitted radiation. The average dose rate due to these radionuclides was $5.36 \mu \mathrm{Gy} \mathrm{y}^{-1}$, a value six orders of magnitude smaller than the threshold value of absorbed dose rate used in this study $\left(3.6510^{3} \mathrm{mGy}^{-1}\right)$, and similar to that found in the literature for benthic fish. Ra-226 and U238 contributed $67 \%$ and $22 \%$ of the absorbed dose rate, followed by Th-232 with $10 \%$. Ra-228 and $\mathrm{Pb}-210$, in turn, accounted for less than $1 \%$ of the absorbed dose rate. This distribution is somewhat different from that reported in the literature, where the Ra-226 accounts for $86 \%$ of the absorbed dose rate.
\end{abstract}

\section{R E S UM O}

Visando a radioproteção ambiental, baseada no conceito de limite de taxa de dose absorvida, foi desenvolvida uma metodologia de conversão da concentração de atividade de radionuclídeos $\left(\mathrm{Bq} \mathrm{kg}^{-1}\right)$ em taxa de dose absorvida $\left(\mathrm{Gy} \mathrm{a}^{-1}\right)$. $\mathrm{O}$ modelo considera apenas a taxa de dose absorvida interna. Essa metodologia foi aplicada ao peixe vermelho-caranho (Lutjanus cyanopterus, Cuvier, 1828) capturado na costa do Ceará e aos radionuclídeos naturais: urânio-238, rádio-226, chumbo210 , tório-232 e rádio-228. As taxas de dose absorvidas foram calculadas por radionuclídeo e por tipo de radiação emitida. A taxa de dose média devida a esses radionuclídeos foi de $5.36 \mu \mathrm{Gy} \mathrm{a}^{-1}$, valor seis ordens de grandeza menor que o valor de limite de taxa de dose absorvida utilizada no presente trabalho $\left(3.6510^{3} \mathrm{mGy} \mathrm{a}^{-1}\right)$, e similar ao encontrado na literatura para peixes bentônicos. Ra-226 e U-238 contribuíram com $67 \%$ e $22 \%$ da taxa de dose absorvida, seguidos de Th-232 com 10\%. Já Ra-228 e Pb-210 respondem por menos de $1 \%$ da taxa de dose absorvida. Essa distribuição é um pouco diferente do relatado na literatura, onde Ra-226 responde por $86 \%$ da taxa de dose absorvida.

Descriptors: Environmental radioactivity, Environmental radioprotection, Biota dose, Natural radionuclides, Cubera snapper.

Descritores: Radioatividade ambiental, Radioproteção ambiental, Dose na biota, Radionuclídeos naturais, Vermelho-caranho. 


\section{INTRODUCTION}

Life arose and evolved in a constantly irradiated environment. Some authors point to ionizing radiation as one of the factors involved in biological evolution, allowing for greater gene flow (ODUM, 1986; ODUM; BARRETT, 2007; MARGALEF, 1982; BEGON et al, 2007). There are three major sources of ionizing radiation: natural radionuclides, cosmic radiation and artificial radionuclides. Natural radionuclides, e.g. uranium, thorium and their daughters, were formed at Earth's origin. Cosmic radiation originates outside the Earth. Since the beginning of the atomic era, a number of radionuclides have been produced by man and released into the environment.

Among the natural radionuclides, $\mathrm{K}-40$ is responsible for $90 \%$ of the activity present in seawater (JIMONET; METIVIER, 2007). This absolute predominance is not, however, reflected in the activity observed in marine organisms. Potassium concentrations are under physiological control and efficient accumulation mechanisms of Po-210, an alpha-emitter of short half-life (138.4 days), turn it into the radionuclide that contributes most to the internal dose (AARKROG et al., 1997; PEREIRA, 1995, 1999). Among artificial radionuclides, Cs-137 is the most important, due to its large-scale production in nuclear reactions and its high biological availability and half-life (30.1 years) (AARKROG et al., 1997).

Environmental radioprotection is based on a former proposal of the International Commission of Radiological Protection - ICRP (ICRP, 1977) that stated that if man is protected, so also will be the environment. This paradigm has been called in question by many authors (WOODHEAD, 1979; AMIRO, 1997; PENTREATH, 1999; PENTREATH; WOODHEAD, 2001; PENTREATH, 2002; WOODHEAD, 2003) and by ICRP itself (ICRP, 1991, 2007). Presently, the ICRP states that the environment must be protected specifically (ICRP, 2003, 2007, 2008).

Currently, there are several proposals to establish the radioprotection of the environment based on the concept of standard dose limit, with evaluation of the absorbed dose rate received by the biota (unit: Gray, symbol Gy, and size of $\mathrm{J} \mathrm{kg}^{-1}$ ). Several countries have made efforts to consolidate this form of radioprotection: USA (NCRP, 1991; US DoE, 2002), UK (COPPLESTONE et al., 2001) and Canada (ENVIRONMENT CANADA, 2001).

Other approaches to the radioprotection of non-human biota have been proposed, such as the Ecological Risk Assessment (ERA) proposed by USEPA (1998), BIRD et al. (2003) and BRECHIGNAC (2003), or the use of a flora and fauna reference series of organisms. The latter view is an attempt to reproduce for the biota the concept of 'man reference', proposed by the ICRP (1977) and maintained in the ICRP recommendations of 1991 and 2007 (ICRP, 1991, 2007), and still used in human radioprotection. This latter approach has been proposed by IAEA (1979); AMIRO (1997); Pentreath; Woodhead (2001); ICRP (2003); Larson et al. (2004); Hinton et al. (2004); Brown et al. (2006) and Copplestone et al. (2008).

To achieve radioprotection based on the concept of a standard dose limit, there is the need of a model to transform the exposure to radiation fields and contamination with radionuclides into an absorbed dose rate. The first step to calculate the increase in dose rate in biota is to establish the baseline of the absorbed dose rate to which organisms are exposed. This study aims to assess the concentration of natural radionuclides of the uranium series (isotope 238 of uranium, U-238; isotope 226 of radium, Ra-226 and isotope 210 of lead, $\mathrm{Pb}-210$ ) and of the thorium series (isotope 232 of thorium, Th-232 and isotope 228 of radium, $\mathrm{Ra}-228$ ) in the cubera snapper fish caught off the coast of Ceará. It also seeks to use the framework for radioprotection of biota based on the concept of standard dose limit proposed by Pereira et al. (2008). This concept has been applied to continental water ecosystems and here it is adapted to the marine environment.

\section{Material and Methods}

\section{Framework for Radioprotection of Non-Human Biota}

The framework for protecting non-human biota used is based on the standard dose limit concept in accordance with the approach proposed by Pereira et al. (2008) and based on the following assumptions: (1) the dose rate considered is the internal dose; (2) doses from exposure to radionuclides present in water and sediment have not been taken into account; (3) the alpha, beta and gamma emitter radionuclides are considered to be homogeneously distributed within the organism; (4) the alpha radiation is totally absorbed by the organism, and finally (5) in order to be conservative within an environmental protection perspective, all beta and gamma energy has been assumed to be absorbed.

The internal dose rate is calculated, in $\mu \mathrm{Gy}$ $\mathrm{y}^{-1}$ from the activity concentrations of the radionuclide, obtained in $\mathrm{Bq} \mathrm{kg}{ }^{-1}$ fresh weight, as follows:

for alpha-emitter:

$\mathrm{D}_{\alpha}=5.05 \mathrm{E}_{\alpha} \mathrm{N}_{\alpha} \Phi \mathrm{C}_{0} \quad \mu \mathrm{Gy} \mathrm{y}^{-1}$ 
for beta-emitter:

$\mathrm{D}_{\beta}=5.05 \mathrm{E}_{\beta} \mathrm{N}_{\beta} \Phi \mathrm{C}_{0} \quad \mu \mathrm{Gy} \mathrm{y}^{-1}$

for gamma-emitter:

$\mathrm{D}_{\gamma}=5.05 \mathrm{E}_{\gamma} \mathrm{N}_{\gamma} \Phi \mathrm{C}_{0} \quad \mu \mathrm{Gy} \mathrm{y}^{-1}$

where:

- 5.05 is the dose conversion factor $\left[\left(\mu \mathrm{Gy} \mathrm{y}^{-1}\right)(\mathrm{Bq}\right.$ $\left.\left.\mathrm{kg}^{-1}\right)^{-1}\right]$;

- $E_{\alpha}, E_{\beta}$ and $E_{\gamma}$ are the energies of the alpha, beta and gamma radiations respectively $(\mathrm{MeV})$;

- $\mathrm{N}_{\alpha}, \mathrm{N}_{\beta}$ and $\mathrm{N}_{\gamma}$ are the amount of transition energy produced by an alpha particle, beta particle or a gamma ray (dimensionless);

- $\Phi$ is the amount of absorbed energy (dimensionless) and;

- $\mathrm{C}_{0}$ is the activity concentration of the radionuclide in the organism ( $\mathrm{Bq} \mathrm{kg}^{-1}$, fresh weight).

For the calculation of the total internal dose $\left(D_{i}\right)$, the sum of the contributions of alpha, beta and gamma radiations was considered, as follows:

$\mathrm{D}_{\mathrm{i}}=\mathrm{D}_{\alpha}+\mathrm{D}_{\beta}+\mathrm{D}_{\gamma} \quad \mu \mathrm{Gy} \mathrm{y^{-1 }}$

\section{Biological Material: Collection and Preparation}

The fish cubera snapper (Lutjanus cyanopterus, Cuvier, 1828) was chosen to test the methodology. An aggressive, carnivorous fish, the cubera snapper feeds primarily on fish and crabs. Their strong canines allow mature cubera to feed on large crustaceans including lobsters and crabs. Their feeding grounds are typically located near the bottom in rocky reef areas or adjacent to other structures. The cubera snapper is considered "Vulnerable" by the International Union for Conservation of Nature and Natural Resources (IUCN, 2010). Six specimens of the cubera snapper were purchased at the fish market on the Praia da Jurema, Fortaleza, Ceará (Brazil) in February, 2007; eight specimens were collected in June, 2007 and another seven in September, 2007. The fish were stored in plastic bags and transported to the Laboratory of Analytical Chemistry of the Federal University of Ceará (UFC). The whole fish was weighed and dried at constant weight, at $80^{\circ} \mathrm{C}$. The biological material was then sent to the Laboratory of Environmental Monitoring of the Ore Treatment Unit (UTM), Brazilian Nuclear Industries (INB). Each whole animal was reduced to ashes at $450^{\circ} \mathrm{C}$ to yield a pale residue which was homogenized in a mortar and from which aliquots were taken for analysis.

\section{Radionuclides}

The radionuclides investigated belong to the U-238 and Th-232 series: U-238, Ra-226 and Pb-210, of the U-238 family, and Th-232 and Ra-228, of the Th-232 family.

Uranium and thorium were measured by spectrophotometry using the arsenazo method (SAVVIN, 1961, 1964). Ra-226 activity was determined by radiochemistry and total alpha radiometry, and that of $\mathrm{Ra}-228$ and $\mathrm{Pb}-210$ by radiochemistry and total beta radiometry, as described by Godoy et al.(1994).

The energies of the radiations $\left(\mathrm{E}_{\alpha}, \mathrm{E}_{\beta}\right.$ and $\left.\mathrm{E}_{\gamma}\right)$ and the amount of the transitions $\left(\mathrm{N}_{\alpha}, \mathrm{N}_{\beta}\right.$ and $\left.\mathrm{N}_{\gamma}\right)$ for all the radionuclides studied are shown in Table 1 . The value of $\Phi$ for alpha, beta and gamma radiations has been stated as equal to 1 .

Table 1. Amounts of transitions that produce particles and radiation, and energies of particles and radiation emitted by the radionuclides analyzed (in MeV) following ICRP (1983).

\begin{tabular}{lllllll}
\hline \hline Radionuclide & $\mathbf{N}_{\boldsymbol{\alpha}}$ & $\mathbf{E}_{\boldsymbol{\alpha}}$ & $\mathbf{N}_{\boldsymbol{\beta}}$ & $\mathbf{E}_{\boldsymbol{\beta}}$ & $\mathbf{N}_{\gamma}$ & $\mathbf{E}_{\gamma}$ \\
\hline U-238 & 1 & 4.26 & 0 & n.a. & 1 & $1.3610^{-3}$ \\
Ra-226 & 1 & 4.86 & 0 & n.a. & 1 & $6.4710^{-3}$ \\
Pb-210 & 0 & n.a. & 1 & $3.8010^{-2}$ & 1 & $4.8110^{-3}$ \\
Th-232 & 1 & 4.07 & 0 & n.a. & 1 & $1.3310^{-3}$ \\
Ra-228 & 0 & n.a. & 1 & $1.6910^{-2}$ & 1 & $4.1410^{-9}$ \\
& & & & & &
\end{tabular}

Legend: n.a. $=$ not applicable; $\mathrm{E}_{\alpha}, \mathrm{E}_{\beta}$ and $\mathrm{E}_{\gamma}$ are the energies of the alpha, beta and gamma radiations respectively in $\mathrm{MeV} ; \mathrm{N}_{\alpha}, \mathrm{N}_{\beta}$ and $\mathrm{N}_{\gamma}$ are the amount of transitions that produces an alpha particle, beta particle or a gamma ray (dimensionless).

\section{Limits of Absorbed Dose Rate}

In Brazil, no limits have been established for the absorbed dose rate by biota. In some countries, the model proposed by the International Atomic Energy Agency (IAEA, 1979) has been adopted. This is the case of the Department of Energy of the United States (US DoE) that uses the value proposed by IAEA, which is stated as $10 \mathrm{mGy} \mathrm{d}^{-1}$ (US DoE, 2002). The same value, expressed on an annual basis, i.e. 3.65 $10^{3} \mathrm{mGy}^{-1}$ (CNEN, 2005), will be used in this work as dose rate limit.

\section{RESULTS AND Discussion}

The Ceará region is considered by Santos et al. (2008) and Marques Júnior et al. (2009) as an area of normal natural radioactivity, and this has been corroborated by the values of the activity concentrations of the natural radionuclides analyzed here, and the respective doses they provided. 
The activity concentrations (in $\mathrm{Bq} \mathrm{kq}^{-1}$, in fresh weight) of U-238, Ra-226, Pb-210, Th-232 and $\mathrm{Ra}-228$ in the cubera snapper (Lutjanus cyanopterus, Cuvier 1828) are shown in Table 2 and are compared with world average values for U-238, Ra-226 and Th-232 (CHERRY; SHANNON, 1974; BROWN et al., 2004). The mean U-238 values found in this study are one order of magnitude higher than the world average (CHERRY; SHANNON, 1974; BROWN et al., 2004). For Ra-226, the values found were comparable to those given in the literature (CHERRY; SHANNON, 1974; BROWN et al., 2004), and the values for Th-232 were two orders of magnitude greater than those reported by Brown et al. (2004). No comparison could be made for Pb-210 and Ra-228, since no world average values could be found in the literature. This might be due to the fact that neither of these radionuclides is an alpha emitter (CHERRY; SHANNON, 1974) and both have been less studied (BROWN et al., 2004).

Some nuclides showed values comparable to world average values and others did not. Due to the sparse data available on Brazilian fishes, it can only be speculated that such differences may be attributable to a number of biological, ecological and physicochemical factors. Such differences may be due to the sample used in this study (the whole fish), while part of the literature uses selected parts of the fish. Other biological reasons may be evoked such as, i.a., the position of the fish in the food-chain that may result in different susceptibilities to accumulate nuclides and the physiology of the fish itself. Among possible ecological reasons, one may mention the habitat of the fish, its ecological niche, the community composition that modulates the radionuclide availability through the food-chain, the age distribution of fish in the population and their feeding habits. All this, combined with the specific affinities of the radionuclides for some tissues and/or species leads to a singular biological availability for each nuclide in each fish species. In fact, it is not to be expected that a single fish species (here the cubera snapper) should mimic exactly the fish world average values for each nuclide.

The average activity concentration values, shown in Table 2, were used for the assessment of internal exposure, in terms of absorbed dose rate, and were compared with the values found in the literature (BROWN et al., 2004) and with the proposed limit. The values of absorbed dose rate (in $\mu \mathrm{Gy} \mathrm{y}^{-1}$ ) were obtained using equations (1), (2), (3), and (4) and were analyzed in terms of the radionuclide and the kind of radiation emitted. The values of absorbed dose rate found are shown in Table 3, as well as the values reported in the literature shown as global means.

Table 2. Average activity concentrations (in $\mathrm{Bq} \mathrm{kg}^{-1}$, fresh weight) of the radionuclides analyzed in the fish cubera snapper from the coast of Ceará, Brazil.

\begin{tabular}{lllllll}
\hline \hline Month & U-238 & Ra-226 & Pb-210 & Th-232 & Ra-228 & n \\
\hline February & 0.061 & 0.280 & 0.040 & 0.033 & 0.650 & 6 \\
June & 0.077 & 0.100 & 0.100 & 0.017 & 0.190 & 8 \\
September & 0.028 & 0.170 & 0.170 & 0.027 & 0.530 & 7 \\
Average in this study & 0.055 & 0.183 & 0.103 & 0.026 & 0.457 & 21 \\
Average of Cherry and Shannon, 1974 & 0.0026 & 0.12 & n.d. & n.d. & n.d. & n.d. \\
Average of Brown et al., 2004 & 0.008 & 0.2 & n.d. & 0.0007 & n.d. & n.d. \\
\hline
\end{tabular}

n.d. $=$ not determined

Table 3. The internal absorbed dose rate in cubera snapper $\left(\mu \mathrm{Gy} \mathrm{y}^{-1}\right)$ per radionuclide and radiation type.

\begin{tabular}{|c|c|c|c|c|c|}
\hline \multirow{2}{*}{ Radionuclide } & \multirow{2}{*}{$\begin{array}{l}\text { Mean of absorbed dose rate } \\
\left(\text { BROWN et al., 2004) }\left(\mu \mathrm{Gy} \mathbf{y}^{-1}\right) \text {. }\right.\end{array}$} & \multicolumn{4}{|c|}{ Absorbed dose rate per radiation type $\left(\mu \mathrm{Gy} \mathbf{y}^{-1}\right)$. } \\
\hline & & Alfa & Beta & Gama & $\begin{array}{l}\text { Total per } \\
\text { radionuclide }\end{array}$ \\
\hline U-238 & 0.42 & 1.189 & n.a. & 0.000 & 1.190 \\
\hline Ra-226 & 34.2 & 3.571 & n.a. & 0.006 & 3.577 \\
\hline $\mathrm{Pb}-210$ & n.d. & n.a. & 0.020 & 0.003 & 0.022 \\
\hline Th-232 & 0.015 & 0.527 & n.a. & 0.000 & 0.527 \\
\hline Ra-228 & 0.0001 & n.a. & 0.039 & 0.000 & 0.039 \\
\hline \multicolumn{2}{|c|}{ Total per radiation type } & 5.287 & 0.059 & 0.009 & \\
\hline \multicolumn{2}{|c|}{ Internal absorbed dose rate } & 5.355 & & & \\
\hline
\end{tabular}


The absorbed dose rate found was 5.36 $\mu \mathrm{Gy} \mathrm{y}^{-1}$, a value less than $0.00014 \%$ of the limit of absorbed dose rate used in this study $\left(3.6510^{3} \mu \mathrm{Gy}\right.$ $\left.\mathrm{y}^{-1}\right)$. The observed value corresponds to $16 \%$ of the value reported in the literature as world average, given as $34.6 \mu \mathrm{Gy} \mathrm{y}^{-1}$ (BROWN et al., 2004).

Regarding the composition of the absorbed dose rate, the most important radionuclide was the alpha emitter Ra-226, with $67 \%$ of the absorbed dose rate. The proportion of absorbed dose rate due to this radionuclide, reported in the literature, is $86 \%$ (BROWN et al., 2004), a value $20 \%$ higher than that observed in this study. The second in importance was U-238, with $22 \%$ of the contribution. Finally, Th-232 contributed with only $10 \%$ of the absorbed dose rate. The contributions of the other radionuclides analyzed ( $\mathrm{Pb}-210$ and $\mathrm{Ra}-228)$ were considered negligible, as they were less than $1 \%$ of the total (Fig. 1).

Differences in the dosimetric models used in this study and by Brown et al. (2004) are reflected in the assessment of the radiological environmental impacts. Thus similar results may lead to different assessments, depending on the model used. For example, Ra-226 values of $0.18 \mathrm{~Bq} \mathrm{~kg}^{-1}$ (this study) and $0.20 \mathrm{~Bq} \mathrm{~kg}^{-1}$ (BROWN et al., 2004) generated impact assessments with one order of magnitude of difference $\left(5.36 \mu \mathrm{Gy} \mathrm{y}{ }^{-1}\right.$ in this study, $34.2 \mu \mathrm{Gy} \mathrm{y}^{-1}$ in Brown et al., 2004). These differences in values, in this case, were not important in deciding the estimate of the Radiological Environmental Impact in Biota $\left(\mathrm{REI}_{\mathrm{B}}\right)$ since, in both approaches, the $\mathrm{REI}_{\mathrm{B}}$ was negligible (less than $1 \%$ of the limit of absorbed dose rate).
Another important question to be discussed is the value of absorbed dose rate limit adopted by this study. For U-238, the activity concentration value that produces the absorbed dose rate limit according to equation (1) is $1.7510^{5} \mathrm{~Bq} \mathrm{~kg}$. According to the Brazilian norm for radioactive waste (CNEN, 1985), materials with activity concentrations above $7.510^{4} \mathrm{~Bq} \mathrm{~kg}^{-1}$ may not be deposited in landfills. This type of material must be dumped in licensed radioactive waste deposits with a view to environmental protection.

This incongruence is due to the concept used to calculate the dose rate limit in the non-human biota, which was developed with a view to the protection of populations only from the deterministic effects of radiation, that is from the injuries characterized by a threshold dose and whose severity increases with increasing dose. Stochastic effects, for which the probability of an effect occurring, but not its severity, is regarded as a function of dose without threshold, are not considered for the biota. This approach differs from that used for establishing the dose rate limit for humans which aims at the protection of populations in such a way as to avoid the deterministic effects of radiation and to reduce the probability of stochastic effects, as well as being committed to reducing doses as far as possible. For non-human biota, there is no mention of stochastic effects (that lead to malignant diseases and inheritable problems), whose effects on populations can only be observed when a variation in their composition, such as an increase in the mortality rate or a reduction in birth rate, occurs.

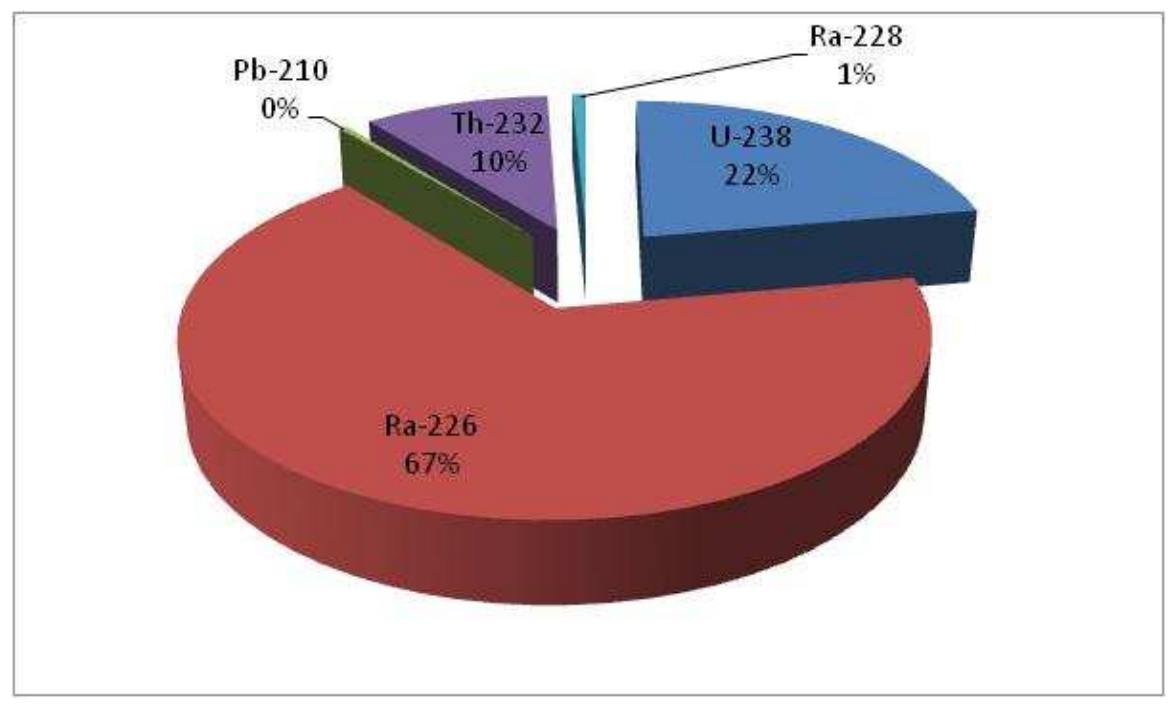

Fig. 1. Contribution of radionuclides analyzed to the absorbed dose rate. 
There is a need for further studies in the quest for better approaches to the protection of the biota from the deleterious effects of radiation. An approach based on deterministic effects on the individual rather than on the population, associated with the reduction of the probability of radiation's stochastic effects also on the individual, associated with the commitment to keep doses as low as possible would lead to the establishment of more realistic dose limits than those in use today. This approach was recommended for human radioprotection by the ICRP in 1977 (ICRP, 1977) and has been maintained in subsequent recommendations (ICRP, 1991, 2007). It has met with world-wide acceptance. Finally, the base of the structure used by countries for human protection should also be used for the radioprotection of the biota.

\section{Conclusions}

The methodology of the standard dose limit used here was appropriate to assess the $\mathrm{REI}_{\mathrm{B}}$ of natural radionuclides in the fish cubera snapper from the coast of Ceará. It was concluded that these radionuclides, in this fish, are not a concern in terms of environmental radioprotection.

Additional relevant information obtained in this study concerned the composition of the absorbed dose rate. It indicated Ra-226 as the critical natural radionuclide, i.e. the radionuclide that is responsible for most of the absorbed dose rate among the nuclides considered here.

A significant limitation for assessments in terms of radioecology and environmental radioprotection is the lack of data on natural radionuclides in fish from the Brazilian coast, which makes radioecological comparisons with other regions of Brazil impossible. Another great limitation is that the study is restricted to only one species of fish, which, again, prevents a reasonable radioecological characterization. The analysis of other members of the ecosystem, such as fish from different habitats, position in the food chain etc., and other members of the biota is of the utmost importance for such characterization. In addition, the evaluation of other natural radionuclides, primarily the alpha emitter Po210, which according to Aarkrog et al. (1997) is the major contributor to the dose in the biota, rather than other uranium isotopes (U-235 and U-234) and thorium isotopes (Th-230 and Th-228), could, to some extent, alter the framework outlined in this work.

Finally, the limit value for absorbed dose rate in fish, equal to 3.65 Gy $\mathrm{y}^{-1}$, calls for better assessment, as the anthropocentric approach leads to more restrictive values than those accepted, from practices, for emissions of radionuclides into the environment.

\section{ACKNOWLEDGMENTS}

We are indebted to Ivan Moura Antunes, in charge of the Environmental Monitoring Laboratory and coordinator of the Coordination of Radiological Protection and Safety of the Ore Processing Unit, Nuclear Industries of Brazil (UTM-INB S/A), for the analyses of fish. We are also grateful to Dr. Helena Becker of the Laboratory of Analytical Chemistry, Institute of Chemistry of the Federal University of Ceará, for the initial processing of the biological material collected, and to the Nuclear Industry of Brazil for the financial support that made the three collections of cubera snapper along the coast of Ceará possible.

\section{REFERENCES}

AARKROG, A.; BAXTER, M. S.; BETTENCOURT, A. O.; BOJANOWSKI, R.; BOLOGA, A.; CHARMASSON, S.; CUNHA, I.; DELFANTI, R. A comparison of doses from ${ }^{137} \mathrm{Cs}$ and ${ }^{210} \mathrm{Po}$ in marine food: A major international study. J. environ. Radioactivity, v. 34, n. 1, p. 69-90, 1997.

AMIRO, B. D. Radiological dose conversion factor for generic non-human biota used for screening potential ecological impacts. J. environ. Radioactivity, v. 35, n. 1, p. 35-51. 1997.

BEGON, M.; TOWNSEND, C. R.; HARPER, J. L. Ecologia: do indivíduo ao ecossistema, 4.ed. Porto Alegre: Artmed, 2007. Reimpressão, 2008. 740 p.

BIRD, G. A.; THOMPSON, P. A.; MACDONALD, C. R.; SHEPPARD, S. C. Ecological risk assessment approach for the regulatory assessment of the effects of radionuclides released from nuclear facilities. INTERNATIONAL SYMPOSIUM ON PROTECTION OF THE ENVIRONMENT FROM IONIZING RADIATION (SPEIR 3), 3., $2003 . \quad$ Vienna: International Atomic Energy Agency (IAEA), 2003. p.241-247.

BRECHIGNAC, F. Protection of the environment: how to position radioprotection in an ecological risk assessment perspective. Sci. tot. Environment, v. 307. p. 35-54. 2003

BROWN, J. E.; JONES, S. R.; SAXÉN, R.; THORRING, R ; BATLLE, J. V. Radiation dose rates to aquatic organisms from natural radionuclides. J. Radiol. Protect., v. 24, p. A24-, 2004.

BROWN, J. E.; HOSSEINI, A.; BØRRETZEN, P; THØRRING, H. Development of a methodology for assessing the environmental impact of radioactivity in Northern Marine environments. Mar. Pollut. Bull., v. 52, p1127-1137, 2006.

CHERRY, R. D.; SHANNON, L. V. The alpha radioactivity of marine organisms. Atomic Energy Rev., v.12, n. 1, p. 3-45. 1974.

CNEN (COMISSÃO NACIONAL DE ENERGIA NUCLEAR). Norma CNEN-NE-6.05, Gerência de rejeitos radioativos em instalações radiativas, 36 p. 1985. 
CNEN (COMISSÃO NACIONAL DE ENERGIA NUCLEAR). Norma CNEN-NN-3.01, Diretrizes básicas de proteção radiológica. Rio de Janeiro: 2005. $34 \mathrm{p}$.

COPPLESTONE, D.; BIELBY, S.; JONES, S. R.; PATTON, D.; DANIEL, P.; GIZE, I. Impact assessment of ionizing radiation on wildlife. R\&D Public.., n. 128, 134 p., 2001

COPPLESTONE, D.; HINGSTON, J.; REAL, A. The development and purpose of the FREDERICA radiation effects database, J. environ. Radioactivity, v. 99, p. 1456-1463, 2008.

ENVIRONMENT CANADA. Releases of radionuclides from nuclear facilities (impact on non-human biota). Priority Substance List Assessment Report. Environment Canada/Health Canada, 2001. $164 \mathrm{p}$

GODOY, J. M.; LAURIA, D. C.; GODOY, M. L. P.; CUNHA, R. Development of a sequential method for determination of ${ }^{238} \mathrm{U},{ }^{234} \mathrm{U},{ }^{232} \mathrm{Th},{ }^{230} \mathrm{Th},{ }^{228} \mathrm{Th},{ }^{228} \mathrm{Ra}$, ${ }^{226} \mathrm{Ra}$ and ${ }^{210} \mathrm{~Pb}$ in environmental samples. $\mathbf{J}$. radioanalyt. nucl. Chem., v. 182, n. 1, p. 165-169, 1994.

HINTON, T. G.; BEDFORD, J. S.; CONGDON, J. C.; WHICKER, F.W. Effects of radiation on the environment: a need to question old paradigms and enhance collaboration among radiation biologists and radiation ecologists. Radiat. Res., v. 162, p. 332-338, 2004.

HIGLEY, K. A.; DOMOTOR, S. L.; ANTONIO, E. J.; KROCHER, D.C.. A derivation of a screening methodology for evaluating radiation dose to aquatic and terrestrial biota. J. environ. Radioactivity, v. 66, p. 4159, 2003a.

IAEA (INTERNATIONAL ATOMIC ENERGY AGENCY). Methodology for assessing impacts of radioactivity in aquatic ecosystems. Tech. Rep. Ser., Vienna, n. 190, 1979.

ICRP (INTERNATIONAL COMMISSION ON RADIOLOGICAL PROTECTION). Recommendations of the International Commission on Radiological Protection. Oxford: Pergamon Press, 1977. ICRP Publication 26.

ICRP (INTERNATIONAL COMMISSION ON RADIOLOGICAL PROTECTION). Radionuclide transformations energy and intensity of transmissions. Oxford: Pergamon Press, 1983. ICRP Publication 38.

ICRP (INTERNATIONAL COMMISSION ON RADIOLOGICAL PROTECTION). Recommendations of the Intentional Commission on Radiological Protection. Oxford: Pergamon Press, 1991. 201 p. ICRP Publication 60.

ICRP (INTERNATIONAL COMMISSION ON RADIOLOGICAL PROTECTION). A framework for assessing the impact of ionising radiation on nonhuman species. Elsevier, 2003. ICRP Publication 91.

ICRP (INTERNATIONAL COMMISSION ON RADIOLOGICAL PROTECTION). The 2007 recommendations of the international commission on radiological protection. Elsevier, 2007. ICRP Publication 103.

ICRP (INTERNATIONAL COMMISSION ON RADIOLOGICAL PROTECTION). Environmental protection: concept and use of reference animals and plants. Elsevier, 2008. ICRP publication 108.

IUCN (INTERNATIONAL UNION FOR CONSERVATION OF NATURE AND NATURAL RESOURCES). IUCN Red List of Threatened Species. Version 2010.1. <http: //www.iucnredlist.org /apps/redlist/>, accessed on January 5, 2010.

JIMONET, C.; METIVIER, H. Personne competente en radioprotection - Principles de radioprotection, reglementation. 2. ed. Paris: EDP Sciences, 2007.389 p.

LARSON, C-M. The Fasset Framework for assessment of environmental impact of ionizing radiation in European ecossistems - an overview. J. Radiol. Prot. n. 24, p. A1-A12. 2004.

MARGALEF, R. Ecologia. 1a ed. Barcelona: Omega, 1982. $951 \mathrm{p}$.

MARQUES JÚNIOR, A. N. et al. Poluição marinha. In: PEREIRA, R. C.; SOARES-GOMES, A. (Org.). Biologia Marinha. 2.ed. rev. e ampl. Rio de Janeiro: INTERCIÊNCIA, 2009. $631 \mathrm{p}$.

NCRP (NATIONAL COUNCIL ON RADIATION PROTECTION AND MEASUREMENTS). Effects of ionizing radiation on aquatic organisms, NCRP rep. n.109, Bethesda, MD, USA, 1991

ODUM, E. P. Ecologia. 1. ed. Rio de Janeiro: Guanabara, 1986. $433 \mathrm{p}$.

ODUM, E. P.; BARRETT, G. W. Fundamentos de ecologia. Tradução da $5^{\circ}$ edição norte Americana, Thompson, São Paulo: Cengage Learning, 2007. 612 p. Trad.de: Fundamentals of Ecology.

PENTREATH, R. J. A system for radiological protection of the environment: some initial thoughts and ideas. J. Radiol. Protect.. v. 19, p. 117-128. 1999.

PENTREATH R. J.; WOODHEAD D. S. A system for protecting the environment from ionizing radiation: selecting reference fauna and flora, and the possible dose models and environmental geometry that could be applied to them. Sci. total Environment, v. 277. p. 3343. 2001.

PENTREATH. R. J. Radiation protection of people and environment developing a common approach. J. Radiol. Protect. v. 22, p.1-12. 2002.

PEREIRA, W. S. Distribuição corpórea de polônio-210 em três espécies de peixes da Baía de Sepetiba. Monografia (Especialização) - UFF, Instituto de Biologia, Rio de Janeiro, 1995. 62 p.

PEREIRA, W. S. Macrodon Alguns aspectos da bioacumulção de Polônio-210 e Chumbo-210 em ancylodon (Block \& Schenneider, 1864). Dissertação (Mestrado) - UFF, Instituto de Biologia, Rio de Janeiro, 1999. $124 \mathrm{p}$.

PEREIRA, W. S.; KELECOM, A.; PY JUNIOR, D. A. Utilização de peixes como biomonitor para fins de radioproteção ambiental em ecossistemas aquáticos continentais. Um modelo conceitual. Oecol. Brasiliensis, v. 12. n. 3. P. 542-552. 2008

SANTOS, I. R.; BURNETT, W. C.; GODOY, J. M. Radionuclides as tracers of coastal process in Brazil: Review, synthesis, and perspectives. Braz. J. Oceanogr., v. 56, n. 2, p. 115-131, 2008

SAVVIN, S. B. Analytical use of arsenazo III: Determination of thorium, zirconium, uranium and rare earth elements, Talanta, v. 8, n. 9. p. 673-685. 1961. 
SAVVIN, S. B. Analytical applications of arsenazo III-II: Determination of thorium, uranium, protactinium, neptunium, hafnium and scandium, Talanta, v. 11, n. 1, p. 1-6. 1964

US DoE (UNITED STATES DEPARTMENT OF ENERGY). A graded approach for evaluating radiation dose rate to aquatic and terrestrial biota. DOE-std-1153. module 3 methods derivation. 2002. $58 \mathrm{p}$.

USEPA (UNITED STATES ENVIRONMENTAL PROTECTION AGENCY). Guidelines for Ecological Risk Assessment. EPA/630/R-95/002F, Risk Assessment Forum. USEPA, Washington, DC, USA, 1998. 223 p.
WOODHEAD, D. S. Methods of dosimetry for aquatic organisms, in methodology for assessing impacts of radioactivity in aquatic ecosystems. IAEA Tech. Rep., v.190, p. 43-96, 1979.

WOODHEAD, D. S. A possible approach for the assessment of radiation effects on populations of wild organisms in radionuclide-contaminated environments. J. environ. Radioactivity, v. 66, p. 181-213. 2003.

(Manuscript received 03 June 2009; revised 14 April 2010; accepted 07 June 2010) 